\title{
The effect of Covid-19 on the economy of Bangka-Belitung and the performance of MSME and its impact on competitive strategies in the new normal era
}

\author{
Reniati Reniati ${ }^{1}$, Muhammad Faisal Akbar ${ }^{2}$, Nur Ahmad Ricky Rudianto ${ }^{3}$ \\ Management Major, Faculty of Economics, Universitas Bangka Belitung, Kepulauan Bangka \\ Belitung, Indonesia ${ }^{1}$ \\ Economics Study Program, Faculty of Economics, Universitas Bangka Belitung, Kepulauan Bangka \\ Belitung, Indonesia ${ }^{2}$ \\ Accounting Major, Faculty of Economics, Universitas Bangka Belitung, Kepulauan Bangka Belitung, \\ Indonesia ${ }^{3}$ \\ $\underline{\text { r3ni4ti@yahoo.com }}^{1}, \underline{\text { akbarf755@gmail.com }}^{2}, \underline{\text { ahmad.ricky.01@gmail.com }}^{3}$
}

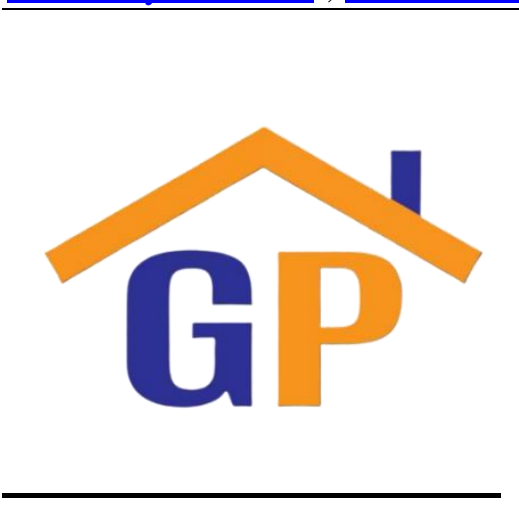

Article History

Received on 19 October 2020

$1^{\text {st }}$ Revision on 22 October 2020

$2^{\text {nd }}$ Revision on 2 November 2020

Accepted on 2 November 2020

\section{Abstract}

Purpose: The economy in the MSME sector is experiencing a great crisis in the face of the Covid-19 pandemic. MSME actors must change strategies to adapt to the current pandemic conditions. The purpose of this study was to examine the effects of Covid 19 on the economy and performance of MSMEs as well as the strategies adopted by MSME players in Bangka Belitung Province.

Research methodology: The data collection method employed probability sampling with google form media analyzed by using cross tabulation, trend analysis and simple mathematical modeling in projecting total economic losses to MSMEs that are active in the Bangka Belitung Island Province.

Results: The results show that 84.7 percent of MSMEs experienced a negative impact due to the Covid 19 pandemic in the form of a decrease in sales turnover, reduced demand and hampered distribution of raw materials. However, 15.3 percent of MSMEs experienced a positive impact and survived in the Covid 19 pandemic conditions. Some of the strategies implemented by MSMEs to survive in the Covid 19 periods were replacing products sold with products for handling COVID 19 such as masks, hand sanitizers and others. MSME players also changed their sales strategy by selling online and maintaining customer databases.

Limitation: Due to the Covid-19 condition, survey activities were carried out by using the Google Form online application.

Contribution: MSMEs undertook a more aggressive marketing strategy to maintain turnover value in order to keep growing.

Keywords: Covid-19, MSME, Turnover, Competitive strategy

How to cite: Reniati, R., Akbar, M. F., Rudianto, N. A. R. (2019). The effect of Covid-19 on the economy of Bangka-Belitung and the performance of MSME and its impact on competitive strategies in the new normal era. Annals of Management and Organization Research, 1(1), 51-63.

\section{Introduction}

Several estimates of the development of Covid-19 provided different data. The State Intelligence Agency on April 2 stated that the peak of Covid in Indonesia was in July 2020 with a total of around 106 thousand cases. Researchers in ITB (Bandung Institute of Technology) on March 27, 
202, stated that the Covid-19 epidemic in Indonesia would last until the end of May/early June. Meanwhile, the Center for Mathematical Modeling of Infectious Disease on March 24, 2020, launched a modeling based on the potential for 70,000 undetected cases of Covid-19 in Indonesia. Finally, Ejkman / Oxford Clincal Research Unit on March 20 stated that the Covid-19 cases in Indonesia could reach 71 thousand cases by the end of April. Jakarta as the capital city has reached the highest number of covid cases, namely $49.1 \%$, followed by West Java $11.8 \%$, then Banten $8.3 \%$, East Java $7.3 \%$ and Central Java 5.7\%, while in areas outside the Island, the highest number is in South Sulawesi, with 3.4\% of this data reported on April 4, 2020, sourced from https://www.covid19.go.id/situasi-virus-corona/ per April 4, 2020.

The humanitarian crisis that spread to the economic crisis led us to start learning to adapt to face the various impacts of Covid-19, namely Digitalization in all aspects of life. In its development, based on a survey from Bank Indonesia released in April 2020. Regarding the impacts of the spread of the Corona Virus on the Performance of MSMEs and BI's Response to the Issuance of Perpu 1/2020, it turns out that 536 or $67.1 \%$ of MSMEs stated that they were affected by Covid-19, the remaining 263 MSMEs or 32.9\% were not affected. From the population of BI-assisted MSMEs throughout Indonesia, as many as 946 MSMEs spread across the Sumatra region, as many as 218 across Java, as many as 311 MSMEs across Kalimantan, as many as 69 MSMEs across Bali and Nusa Tenggara, as many as 51 MSMEs across Sulampua, and as many as 150 confirmed that the number of MSMEs had affected quite significantly. Further data show that MSME Exports and Tourism and their followings such as handicrafts have the deepest impacts. This is due to restricted purchases and export barriers, cancellation of events / MICE, a decrease in the number of tourists, and no operation of places where MSME products are sold. Meanwhile, agricultural MSMEs are affected in a limited way because they are supported by the high demand for food.

MSMEs, as the backbone of the national and regional economies, have indeed suffered a severe blow from Covid-19. If in the economic crisis of 1997/1998 MSMEs were able to survive, on the contrary, during this crisis, many of them collapsed by laying off workers and even closing their businesses. But there are also those who are creatively switching their business, for example, for the textile or garment sector, which usually produces clothes, now they have switched to making masks and PPE clothes. MSMEs related to herbal products have also begun to diversify products, especially for body resistance, vitamin $\mathrm{C}$ drinks from medicinal plants, herbs and even cakes that use emponempon raw materials as their creativity. MSMEs are indeed easier to transform and innovate. This is in accordance with what Tidd and Bessant (2019) arguing that MSMEs are able to innovate, among others because (1) they are quick to make decisions (2) they possess informal culture, (3) they are flexible and agile, and (4) they hold entrepreneurial spirit and low risk. So even though almost 70\% of MSMEs has been affected, they still have room to quickly make decisions to innovate in order to maintain their business in accordance with market conditions in their respective regions. Even MSMEs that have carried out online business strategies have claimed to have increased turnover during the Covid 19 period and survived.

The Ministry of Economic Affairs has mapped the potential of The Winner and Loser from the economic sectors affected by Covid 19 from the most severe to the ones with the least, starting with the most highly impacted ones, including Tourism, Construction, Land-Sea and Air Transportation, Aviation, Finance and Automative. Meanwhile, those that have the potential to become a Sunrise Industry or the winner are the sectors of Agriculture, logistics services, telecommunication suits, electronics, food and beverages, chemical-pharmaceuticals and medical devices, textiles and textile products. If you cluster them, the sectors that will have a high impact are those whose turnover drops above 30 percent, including hotels, restaurants, transportation, travel agents, manufacturing (textiles, chemicals, plastics), building materials, heavy equipment, property and construction and pharmaceuticals. The middle-impacted sectors are those whose turnover drops between 10-30 percent, namely: finance, automotive, shopping centers, livestock, fisheries, distribution / retailer of nonessential goods, plantation commodities, mining, metals and minerals. The sectors with low impact are those whose turnover drops less than 10 percent, including packaging, e-commerce, power plants, medical devices, staple food, distribution / retail essential goods, cigarettes, IT / communications. This does not mean that it will become a sunset industry but it requires a new business strategy to bounce back. 
Business prospects after Covid-19 of course depend on changes in consumer behavior and this must be captured by business people to change their business strategies. Consumers will begin to get used to making online purchases and online payments. This of course must be addressed by business people to prepare an online marketing strategy, then fast and satisfying service and an online payment system via QRIS, for example, which has been prepared by Bank Indonesia. Businesses are not just waiting for customers but must be more aggressive in marketing through various attractive and creative online media. In addition, the prospects for MSME business in the future depend on the extent to which the effectiveness of the policies have been carried out by the Central Government and regional governments in dealing with Covid 19.

\section{Formulation of the problem}

1. How will Covid-19 affect the economy of the Bangka Belitung Islands Province?

2. How is the influence of Covid-19 on the performance of MSMEs in the Bangka Belitung Islands Province?

3. What is the Competitive Strategy for MSMEs in the New Normal Era?

\section{Literature review}

\subsection{Micro, Small and Medium Enterprises (MSMEs)}

The following is the definition of MSMEs according to Kondoy and Rahman (2020).

1. A micro business is a productive business owned by an individual or a business entity that meets the criteria for a micro business

2. Small business is a productive economic business that stands alone, is carried out by individuals or business entities that are not subsidiaries or corporate branches of medium or large businesses.

3. Medium-sized enterprises are productive economic enterprises that are independent, carried out by individuals or business entities that are not subsidiaries or corporate branches of large enterprises with annual net assets as regulated in law.

According to Law Number 20 of 2018, the criteria for MSMEs based on the number of assets and turnover owned by a business are as follows:

1. The micro business group has a net worth of not more than Rp. 50,000,000.00 (fifty million rupiahs) excluding land and buildings for business premises; or have annual sales proceeds of not more than IDR 300,000,000.00 (three hundred million rupiahs).

2. The small business group has a net worth of more than Rp. 50,000,000.00 (fifty million rupiahs) up to a maximum of Rp. 500,000,000.00 (five hundred million rupiahs) excluding land and buildings for business premises; or have annual sales proceeds of more than IDR $300,000,000.00$ (three hundred million rupiah) to IDR 2,500,000,000.00 (two billion five hundred million rupiahs)

3. The medium-sized business group has a net worth of more than Rp. 500,000,000.00 (five hundred million rupiahs) up to a maximum of Rp.10,000,000,000.00 (ten billion rupiash) excluding land and buildings for business premises; or have annual sales proceeds of more than IDR 2,500,000,000.00 (two billion five hundred million rupiah) to IDR 50,000,000,000.00 (fifty billion rupiahs)

The handling carried out by the Indonesian Government to maintain the sustainability of MSMEs in the face of the Covid-19 pandemic crisis is formulated in the form of policies, regulations, programs and facilities. Some special schemes for MSME actors according to Marlinah (2020) are as follows:

1. Small and medium enterprises which are categorized as poor and vulnerable to being affected by Covid-19 will be registered as recipients of social assistance such as the Family Hope Program, food packages, direct cash assistance, reduced basic electricity rates, and preemployment cards.

2. Tax incentives for MSMEs with turnover below Rp. 4,800,000,000 (four billion eight hundred million rupiahs) per year, namely by reducing the final income tax $(\mathrm{PPh})$ for MSMEs from 0.5 percent to 0 percent during the period from April to September 2020. 
3. Relaxation and restructuring of MSME credit in the form of postponement of installments and interest subsidies for recipients of People's Business Credit (KUR), Ultramicro Credit (UMi), LPDB (Revolving Fund Management Institution), and assistance capital from several ministries.

4. Implementing an expansion of financing for MSMEs in the form of a work aid stimulus specifically designed for MSME players affected by Covid-19

5. Ministries, state-owned enterprises and local governments act as a buffer during the recovery and consolidation phase of businesses after the Covid-19 pandemic.

\subsection{Sales}

According to Willy (2020), selling is an activity between the seller and the buyer with the seller's mechanism of handing over goods or services to the buyer aimed at getting income for the seller and fulfill the needs of the buyer. The factors that influence sales include:

1. The condition and ability of the seller

The seller must understand some information such as the characteristics of the products offered, the price, and the terms of sale, in order to convince the buyer and succeed in achieving the expected sales goals.

2. Market conditions

Things that need to be considered are the type of market, buyer groups, purchasing power, and community needs.

3. Capital

Capital is a support in carrying out sales activities.

4. Organizational conditions

There is a difference between the conditions of large and small companies. Large companies have their own divisions in handling sales, while small companies usually do not have a special division, sales activities are carried out by people who carry out other functions.

5. Other factors

Other factors such as advertising, discounts, and gifts to attract more customers.

\subsection{Sales turnover}

According to Sriyanto (2020), selling is an effort made to deliver goods to those in need in exchange for an agreed price. Sales turnover is the accumulation of the sales activities of products and services that are calculated as a whole during a certain period of time continuously in one accounting process. Turnover is the total amount of sales of goods / services within a certain period, which is calculated based on the amount of money earned.

According to Sylvia et al. (2019) the factors that affect the amount of turnover are

1. Internal factors, consisting of the company's ability to manage products, policies in choosing prices, promotions, and distributors who will work with the company.

2. External factors, consisting of national and international economic and trade developments, government policies, and conditions of business competition.

According to Dameria (2016), the increasing sales turnover can be done in the following ways:

1. Looking for new customers by promoting products sold by adding promotional media, or participating in exhibitions.

2. Maintaining old costumers by providing a complementary product from the main product purchased by the customer

3. Increasing the sales volume per customer by increasing the benefits of a product, and offering a new product so that the customer buys more than one item.

4. Giving friendly service to give an impression to the customer to have an indirect impact on the opinions and recommendations expressed by the customer to other potential customers.

\subsection{Competitive strategic}

Strategy is the main key for companies in increasing competitive ability which has an impact on improving company performance. A competitive strategy is the direction of an action and how to allocate company resources to win in business competition (Hartini, 2017). 
Kotler (2012) distinguisthed the company's competitive strategy based on the company's market share (the company's position compared to its competitors, seen from the breadth of its market share), namely the market leader strategy, market chalanger, market follower, and market nicher. The market leader strategy is the strategy chosen if the company becomes the market leader, namely controlling more than $40 \%$ of the market share. Market leader strategies include strategies to defend, attack and expand the total market. Market challenger strategy is the company's strategy in the market challenger position, namely controlling $30 \%$ of the market share. This strategy includes a strategy of attacking both frontal and guerrilla attacks. The market follower strategy is a strategy that the company takes if it controls $20 \%$ of the market share, such as modifying competitors' products. Nicher market strategy is a company strategy oriented to meet the needs of a special group of customers that are not fulfilled by large companies.

Porter (1998) emphasized that the competitive strategy should be based on the company's potentials. Porter distinguished a competitive strategy called a generic strategic, which consists of three components, namely differentiation strategy, cost of leadership strategy and focus strategy. Differentiate strategy is a strategy to win a competition by developing the uniqueness of the products / services being offered. Differentiation can be developed by looking at the sources of uniqueness that exist along the value chain. Companies that try to excel in differentiation must be able to exploit all sources of differentiation while maintaining cost advantages. After knowing the consumer value chain, the company selects value activities that contribute to its competitive strategy. This differentiation is considered high if the products it releases are difficult to imitate and are able to survive in the market. This differentiation is built on the identification of the right source of value and the uniqueness that is not easily imitated by competitors. Not all of the differentiation created is of value to its consumers. The cost of leadership strategy is a strategy to win the competition by developing low-cost products. Low-cost firms typically sell standard or non-attribute products and place great emphasis on gaining a cost advantage from all sources. If a company can achieve and maintain an overall cost advantage and control prices at or near the industry average, then the company will be an above-average company in its industry. At the same or lower prices than its competitors, the lower-cost position of the cost leader translates into higher returns. Focus strategy is a company strategy to win in competition with a focus on a specific target market. Companies can use a differentiation strategy as well as a cost of leadership strategy tailored to the target market being served.

The competitive strategies of Miles and Snow's models are prospective, serving as defender, analyzer, and reactor strategies (Barney \& Griffin, 1992). Prospector strategy, which is a strategy that prioritizes the company's success in innovating, creating new products and new opportunities in the market. The strength of this strategy lies in the company's ability to evaluate business environments. The defender strategy prioritizes market stability which is the target market. This strategy is suitable for companies with few product lines and a narrow market segment. The company is only trying to maintain the market rather than expanding it. This strategy is focused on defending the already controlled market from attacks of competitors. The analyzer strategy prioritizes the analysis of new business ideas before entering the business, always pays attention to the strategies of other companies that have already been in the business, and then imitates the competitors' strategy ideas that have been proven successful. Reactor strategy is a strategy that prioritizes reactions to environmental changes. Reactions are carried out only when there is pressure from the environment forcing the company to change.

\section{Previous research}

Fatimah and Tyas (2020) revealed that the competitive strategy for MSME restaurants in Jember is to set service standards according to health protocols during the Covid-19 pandemic and develop services according to the needs, desires, and changes in consumer styles. Restaurants are also required to maintain consumer confidence and be careful when setting the price of products to be sold.

The strategies for MSMEs to survive the Covid 19 pandemic according to Hardilawati (2020) include selling through e-commerce by utilizing online shopping that is popular with the government, marketing products by utilizing digital technology (digital marketing) to reach more consumers, making improvements of quality products and services, and conducting customer relationship, marketing to create consumer trust, and fostering customer loyalty. 
Nasution (2020) revealed that the Covid-19 pandemic has brought the market to a negative direction due to low investor sentiment. This is also the impact of Indonesia's slow exports to China. Based on the sensitivity analysis, it was found that when there was a $1 \%$ slowdown in the Chinese economy, it would affect and have an impact on the rate of economic growth in Indonesia, which was $-0.09 \%$. This is also in line with the sustainability sensitivity analysis where every $1 \%$ of the European Union's economic slowdown will have an impact on the rate of economic growth in Indonesia, namely $-0.07 \%$, India (-0.02\%), Japan (-0.05\%) and Statesof America (-0.06\%). The same picture also occurs for most commodities, namely, every $10 \%$ decline in the price of crude palm oil (CPO) will have an impact on the Indonesian economy by $0.08 \%$. Meanwhile, it is stated that positive oil is $0.02 \%$, and coal is $-0,07 \%$

Prianto, et al (2020) proved that the readiness of micro business actors is weaker than the readiness of small and medium business actors. This is shown by micro business actors being weak in facing changes so that the sustainability of activities is weak, even though micro business actors get the strongest support from the government.

Sugiri (2020) stated that the MSME sector in Indonesia has experienced the impact of the Covid-19 Pandemic in the form of decreased sales, capital difficulties, product distribution constraints, and difficulty in raw materials. There is a need for several MSME protection schemes carried out by the government, namely, by providing social assistance to poor and vulnerable MSME actors, tax incentives for MSMEs, relaxation and credit restructuring for MSMEs, expansion of MSME working capital financing, placing local governments as a buffer for MSME products, and e-learning training.

\section{Research methodology}

This research was conducted in the Province of Bangka Belitung Islands with the scope of research on the activities of MSMEs in various business aspects such as food, clothing, retail, and others. The data source in this study were primarily obtained from filling out questionnaires of respondents, namely, business actors or MSMEs in the province of the Bangka Belitung islands. This study was also intended to include direct interviews with policy makers and MSME business actors related to the assessment of turnover reduction, especially buyers from outside the Province.

This research used multiple regression to analyze the impact of variables such as government social assistance to MSMEs Strategies to decrease in turnover of their product with 73 samples of MSMEs.

The data population in this study were MSMEs' activities in the Bangka Belitung Islands. The sample of respondents to be interviewed followed probability sampling procedure. Survey activities were carried out by using the Google Form online application with a target of respondents of more than 50 MSMEs.

The variables to be measured include:

1. The Sales Value of MSME Turnover

2. Rate of Change in Turnover after Pandemic

3. Strategies for Survival in the Covid Period 19

This study conducted an analytical method by using cross tabulation, trend analysis and simple mathematical modeling in projecting the total economic losses of MSMEs operating in the Province of Bangka Belitung Islands. Regression models were used to find a conclusion based on empirical modeling. Conducted through statistical testing of 73 respondents with a cross section data structure.

Regression analysis was primarily used for two conceptually distinct purposes. First, regression analysis was widely used for prediction and forecasting, where its use had substantial overlaps with the field of machine learning. Second, in some situations, regression analysis was used to infer causal relationships between the independent and dependent variables. Importantly, regressions by themselves only revealed relationships between a dependent variable and a collection of independent variables in a fixed dataset. To use regressions for prediction or to infer causal relationships, respectively, a researcher carefully justified why existing relationships had predictive power for a new context or why a relationship between two variables had a causal interpretation. The latter is especially important when researchers hope to estimate causal relationships by using observational data (Lindley, 1987).

Cross section data was also susceptible to heteroscedasticity problems, so this research conducted a heteroscedasticity test to overcome ineffective models. In statistics, the Breusch-Pagan 
test, developed in 1979 by Trevor Breusch and Adrian Pagan, was used to test for heteroskedasticity in a linear regression model. It was independently suggested with some extension by $\underline{R}$. Dennis Cook and Sanford Weisberg in 1983 (Cook-Weisberg test). Derived from the Lagrange multiplier test principle, it tested whether the variance of the errors from a regression was dependent on the values of the independent variables. In that case, heteroskedasticity was:

$$
y=\beta_{0}+\beta_{1} x+u_{i}
$$

obtained from this fitted model a set of values for $u_{i}$, the residuals. Ordinary least squares had constrains so that their mean was 0 and so, given the assumption that their variance did not depend on the independent variables, an estimate of this variance could be obtained from the average of the squared values of the residuals. If the assumption was not held to be true, a simple model might be that the variance was linearly related to independent variables. Such a model could be examined by regressing the squared residuals on the independent variables, using an auxiliary regression equation of the form

$$
\widehat{u}=\gamma_{0}+\gamma_{1} x+v
$$

This is the basis of the Breusch-Pagan test. It is a chi-squared test: the test statistic is distributed $n \chi^{2}$ with $k$ degrees of freedom. If the test statistic has a p-value below an appropriate threshold ( $\operatorname{eg} p<0.05)$ then the null hypothesis of homoskedasticity is rejected and heteroskedasticity assumed. If the BreuschPagan test shows that there is conditional heteroskedasticity, one could either use weighted least squares (if the source of heteroskedasticity is known) or use heteroscedasticity consistent standard errors (Gujarati, 2004).

\section{Results and discussion}

\subsection{MSMEs surveys}

After conducting an online survey of 72 MSMEs, the analysis shows the following results:

There are 71 MSMEs spread across 7 cities in the Bangka Belitung Islands.

\section{MSMEs Location}
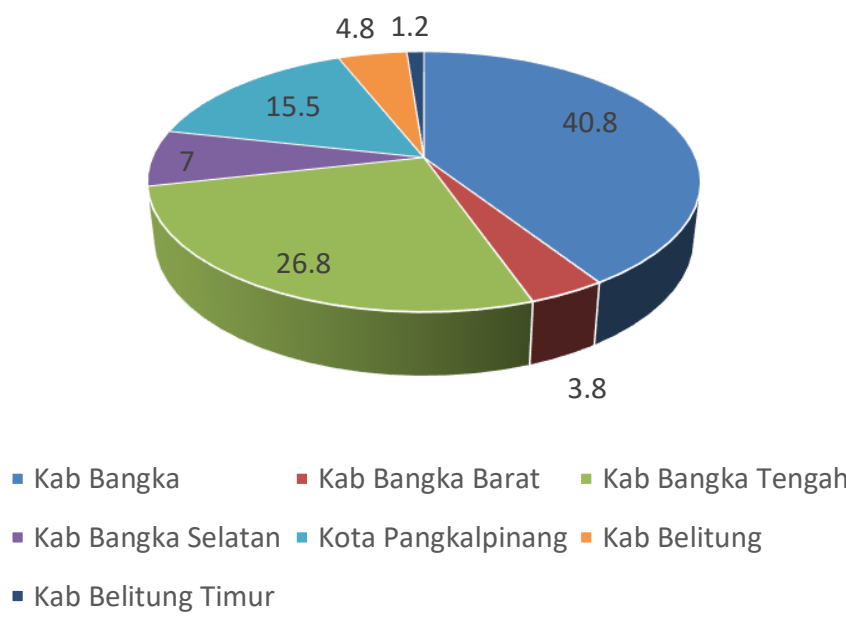

Source: Processed Data

The data show that 63 percent of the MSMEs being surveyed has an average turnover of around below 10 million and the rest has a turnover of above 10 million rupiahs. This value was obtained from the analysis of the comparison of business turnover before and after the pandemic. 


\section{what is the estimated turnover of your business}

\section{per month at pandemic}

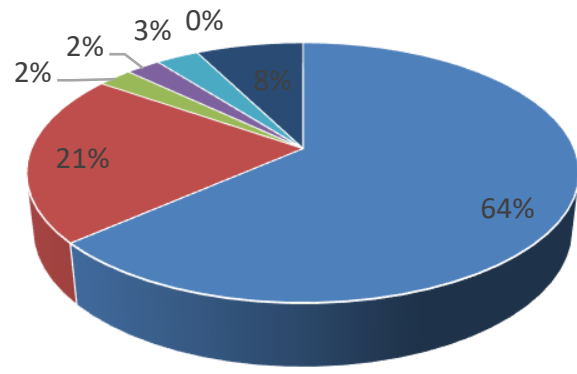

$$
\begin{aligned}
& \text { - Max } 10 \text { Million - } 10 \text { - } 20 \text { million = } 20 \text { - } 30 \text { million } \quad 30-50 \text { million } \\
& \text { - 50-75 million =75-100 million - Above } 100 \text { million }
\end{aligned}
$$

Source: Processed Data

After knowing the average basis of sales turnover per month before the pandemic, the survey continuously conducted to dig up information about the impacts of the pandemic on business activities.

\subsection{The effect of Covid-19 on the economy of Bangka Belitung}

Economic growth is one of the main indicators in measuring the success of development in the regions. The economic growth of Bangka Belitung Province during the 2015-2019 period experienced fluctuating growth but had a downward trend. In 2015 to 2017, economic growth in Bangka Belitung showed an increasing trend from 4.08 percent in 2015 to 4.47 percent in 2017. However, in the 2018 period it began to show a slowdown and fell to 3.32 percent in 2019 .

picture. Economic Growth Development (percent)

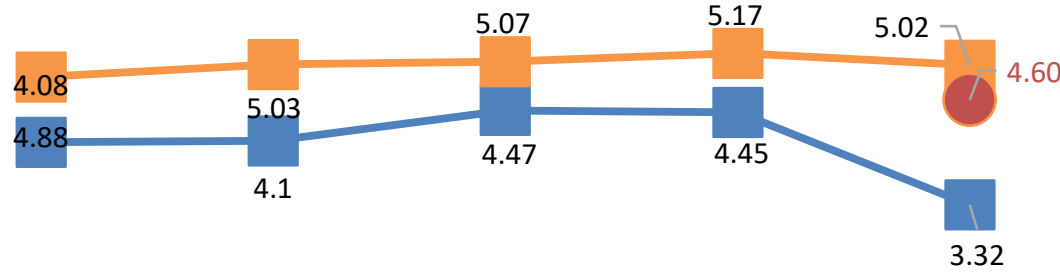
2015
2016
2017
2018
2019
- Provinsi Bangka Belitung
- Target RKPD

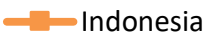

In the first quarter of 2020 economic growth in Bangka Belitung grew by 1.35 percent (c-to-c). The slowdown in economic growth in Bangka Belitung at the beginning of 2020 was caused by the economic performance of several strategic sectors that had decreased, especially in the performance of the primary sector (BPS, 2020). Meanwhile in semester I-2020 (c-to-c) economic growth in Bangka Belitung contracted by minus 1.88 percent. The impact of COVID-19 played a role in the decline in regional economic performance in the first semester of 2020. One of the biggest impacts of COVID-19 came from a decrease in household consumption in line with social restrictions that were implemented 
to reduce the rate of spread of the virus. Judging from the google mobility report data, the study noted that in the period April to June 2020 in Bangka Belitung Province there was a decrease in mobility of up to -22.8 percent, while in July it began to experience relaxation and fell to -13.3 percent.

In addition, in terms of expenditure on foreign export components, Bangka Belitung fell by 23.94 percent due to the decline in demand for tin from the world market as a result of many industries that closed their production activities during the pandemic. In addition, the decline in exports also occurred in other regional superior commodities such as rubber, pepper and CPO (BPS, August 2020). The export performance of Bangka Belitung Province has decreased since March 2020. It was recorded that the cumulative exports from January to June (Semester I-2020) decreased by 26.1 percent (YoY). The main export destination countries for Bangka Belitung Province are Singapore (20 percent), China (16 percent) and South Korea (14 percent). Meanwhile, for exports according to goods, non-tin exports, such as animal fats and oils as well as fish and shrimp have indicated high growth. However, tin, which is the main mining commodity and has a large contribution to total exports, has experienced a deep contraction.

\subsection{The effect of Covid 19 toward business}

The impact of Covid-19 on MSMEs is indeed very significant, from various surveys that have been conducted by Bank Indonesia, BPS and ICSB, stating that the average negative impact is above 60 percent. If during the 1998/1999 crisis, MSMEs were still standing in the face of the crisis due to the Covid-19 pandemic, it turns out that many MSMEs have collapsed.

Look at the following graph.

\section{Covid 19 Impact to your business}

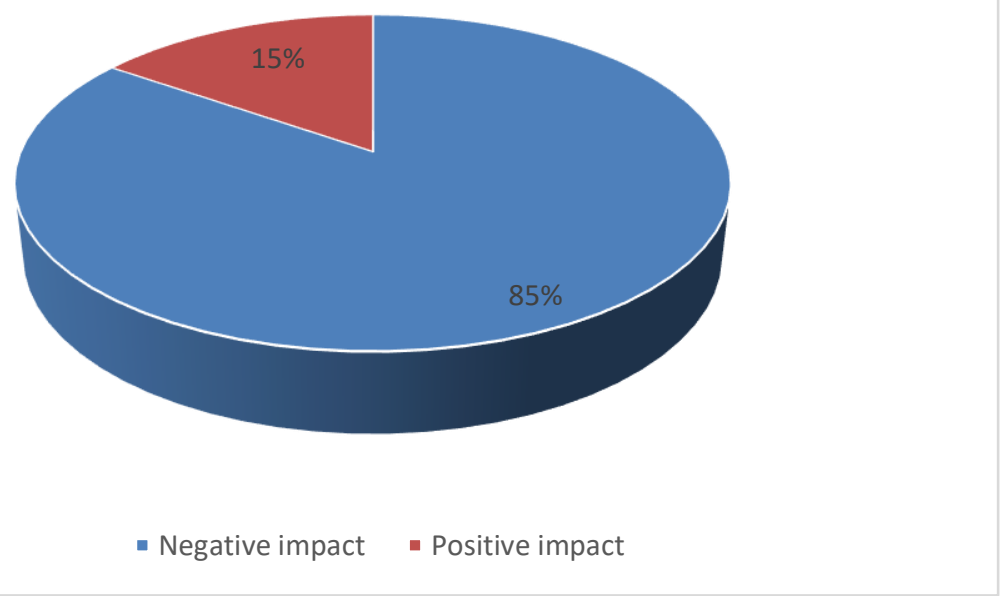

Source: Processed Data

The results show that Covid 19 has a negative impact on 84.7 percent of MSMEs and 15.3 MSMEs claim to be positively affected. This shows that the small and medium business sector is quite responsive to the pandemic. There are still MSMEs that can continue to grow as a result of COVID 19.

The decline in sales is the most dominant factor in influencing MSME businesses. This is due to the existence of several policies during the pandemic such as social distancing, physical distancing, staying at home and large-scale social restrictions (PSBB), as well as the semi-lockdown policy which has resulted in a drastic decrease in human mobility. In addition, this policy has resulted in hampered distribution of both exported and imported goods. This has an impact on the difficulty of obtaining raw materials which hamper production and partly close their business. The business closure has been carried out by laying off employees previously. Of course, the impact of employee housing has resulted in an increase in the number of the unemployed. 


\begin{tabular}{|l|}
\hline MSMEs Impact from COVID 19 \\
\hline decreased sales \\
\hline capital difficulties \\
\hline Hampered distribution \\
\hline raw material difficulties \\
\hline Hampered production \\
\hline Closed business \\
\hline Laid off employees \\
\hline decrease in sales turnover \\
\hline
\end{tabular}

Source: Processed Data

The survey results also show that 75.4 percent of MSMEs experienced a decline in sales and several other MSMEs also experienced difficulties in capital, distribution, raw materials and others.

\subsection{Decrease in sales}

Sales are an important indicator in looking at business performance. Decreasing sales turnover results in disruption of business operations. The impact can be a reduction in operating costs, a reduction in the number of employees. Following are the results of a survey that show the percentage decline in sales turnover due to the impact of Covid 19.

\section{percentage of decrease in turnover during Covid}

19

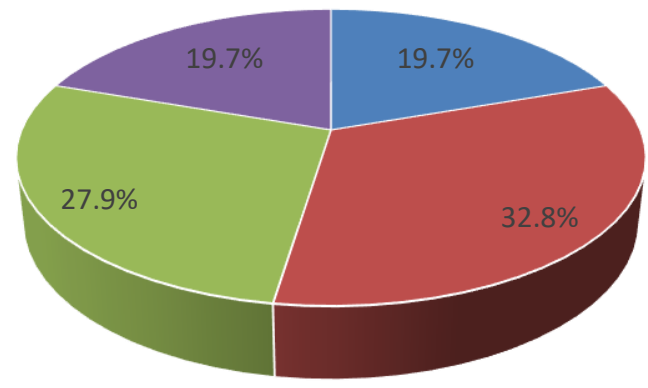

- 10 to 30 percent - 30 to 50 percent $\quad 50$ to 70 percent - above 70 percen

Source: Processed Data

\subsection{Post-Covid-19 competitive strategy}

In facing the current economic recession, MSMEs need new strategies to rise from adversity. Therefore, the strategies they implement vary, involving 4 (four) steps, namely, lowering prices, changing businesses, laying off employees, and making new products. All have been maintained to support family life which is currently experiencing a decrease in income and can lead to decreased welfare. The following are the results of a survey conducted with MSME players on the strategies they have carried out to survive the Covid 19 period.

The survey results indicate that 61 MSMEs out of 72 MSMEs experienced a significant decrease in turnover where 47.6 percent of MSMEs experienced a decrease in turnover above 50 percent. 


\section{MSME strategy to survive the Covid period 19}

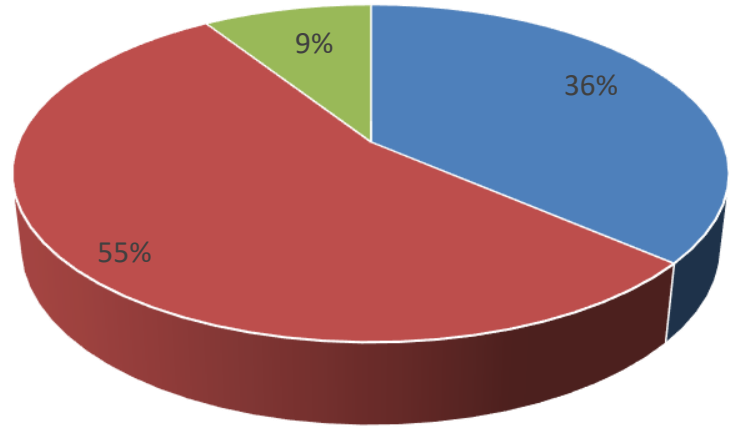

- lowering the price - Change the product $\quad$ - lay off employees

Source: Processed Data

And there were several strategies undertaken by MSMEs to survive including lowering prices, changing products and firing employees.

\subsection{Implementation of the Post-Covid-19 strategy}

After entering the New Normal period, business actors began to implement strategies by following the procedures such as $3 \mathrm{M}$ (wearing a mask, washing hands and maintaining a distance), as well as using gloves, providing headgear, using PPE and measuring body temperature. Based on the results of the survey, the most dominant procedure being followed was providing a place for washing hands $(87.3 \%)$, then using a mask (70.4\%) and providing a hand sanitizer (56.3\%). This step has shown the concern of MSME actors to transform from not caring about health, now prioritizing health and product quality.

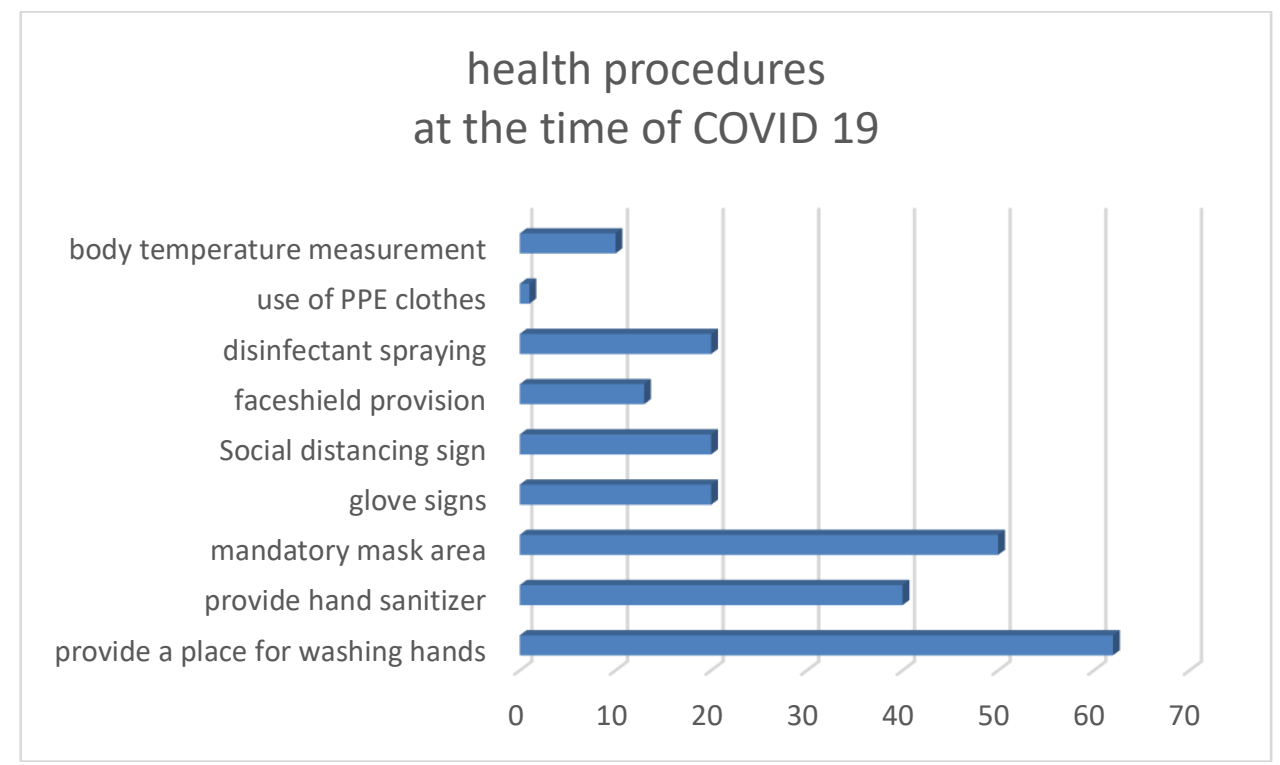

Source: Processed Data

In business behavior, MSMEs are currently taking several steps to make customers and businesses feel more comfortable in conducting transactions by providing a place to wash their hands, use masks and others.

\subsection{The influence of perceptions of MSME players on government assistance and business strategy}

In analyzing the factor of reducing turnover in MSMEs, this study also carried out multiple regressions to see the relationship between the influence of public perceptions on government policies, 
as well as the MSME Development Strategy during the COVID-19 pandemic on reducing turnover. Consider the following results:

Apart from descriptive analysis, this study also analyzed the influence relationship between the perceptions of UMMK players on government assistance and business strategies. The perspective of MSME actors is important to analyze during a pandemic because it shows their optimism or pessimism in running a business. The high impact of the decline in sales made them think about collaborating and synergizing with various parties. In addition, it requires the right strategy to move. So that the business does not collapse and still provides additional income to survive.

The Influence of Perceptions of MSME Players on Government Assistance and Business Strategy.

\begin{tabular}{|c|c|c|c|}
\hline Source & SS & $d f$ & MS \\
\hline Model & 6.90702749 & 4 & 1.72675687 \\
\hline Residual & 51.7370403 & 54 & .958093339 \\
\hline Total & 58.6440678 & 58 & 1.01110462 \\
\hline
\end{tabular}

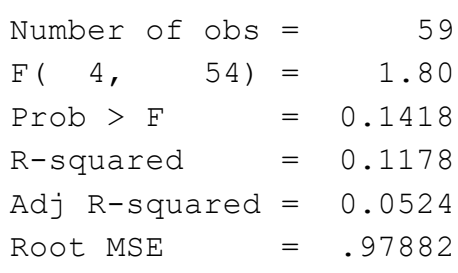

\begin{tabular}{r|rrrrrr}
\hline Y & Coef. & Std. Err. & $t$ & P > t I & [95\% Conf. Interval] \\
\hline X1 & .0253721 & .1101629 & 0.23 & 0.819 & -.1954911 & .2462354 \\
X2 & -.3913753 & .1732952 & -2.26 & 0.028 & -.7388114 & -.0439393 \\
X3 & -.0212969 & .1076976 & -0.20 & 0.844 & -.2372176 & .1946238 \\
X4 & .0897874 & .1762889 & 0.51 & 0.613 & -.2636505 & .4432253 \\
- Cons & 2.128511 & .4889383 & 4.35 & 0.000 & 1.148248 & 3.108773 \\
\hline
\end{tabular}

Source : Processed Data

The results show that the only coefficient that has an effect is the condition in which MSMEs chose to adjust their marketing strategies to have a negative effect on reducing turnover. So it can be concluded that MSMEs chose to adapt by changing their sales products into products related to COVID 19 and doing online marketing aggressively to increase their sales turnover even though the current economic condition is still poor.

Heteroskedasticity Test for Following Regression Model

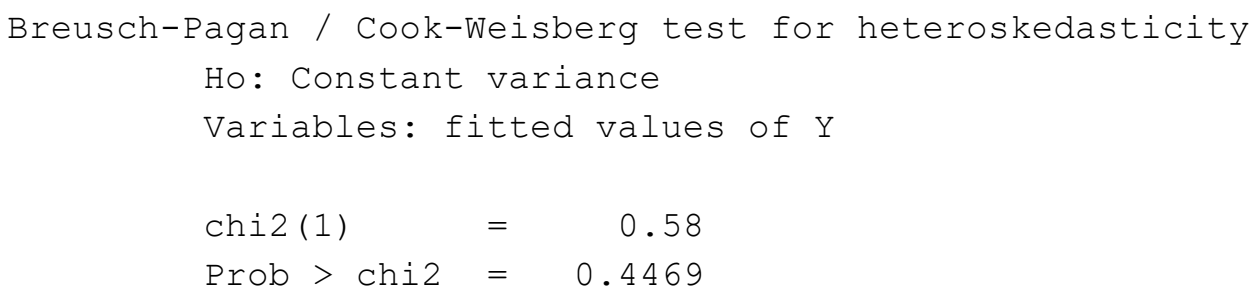

Source : Processed Data

The results of the heteroscedasticity test show that the value Prob> chi2 was higher than alpha. This proves that h0 is accepted, which means that the regression model is homoscedasticity.

\section{Conclusion}

This study identifies MSMEs strategies in surviving the COVID 19 period. After conducting a survey, the data show that around 84.7 percent of MSMEs experienced negative impacts as a result of COVID 19. The negative impacts include a decrease in sales turnover, reduced demand and distribution of raw materials. hampered. However, there are 15.3 percent of MSMEs that are still operating and are 
growing positively along with this pandemic. Some of the strategies implemented by MSMEs to survive the Covid 19 era include replacing products with those for handling COVID 19 such as masks, hand sanitizers and others, conducting online sales, maintaining customer databases, and carrying out more aggressive marketing strategies to keep the turnover value growing.

The government should identify further problems related to providing assistance to MSMEs based on the correct classification. Certain stimulation policies are not able to reach all MSMEs because they have different characteristics.

\section{Reference}

Barney, J. B., \& Griffin, R. W. (1992). The management of organizations: strategy, structure, behavior. United States: Houghton Mifflin College.

Div Cook, R. D., \& Weisberg, S. (1983). Diagnostics for heteroscedasticity in regression. Biometrika, $70(1), 1-10$.

Dameria, I. (2016). Loyalitas konsumen dalam meningkatkan omzet penjualan pada gerai indomaret di kecamatan loceret kabupaten nganjuk. Jurnal aplikasi administrasi, 19(2), 100-109.

Fatimah, F., \& Tyas, W. M. (2020). Strategi Bersaing Umkm Rumah Makan Di Saat Pandemi Covid 19. Jurnal Penelitian IPTEKS, 5(2), 245-253.

Gujarati, D. N. (2004). Basic econometrics (fourth edi).

Hardilawati, W. laura. (2020). Strategi bertahan UMKM di tengah pandemi Covid-19. Jurnal Akuntansi dan Ekonomika, 10(1), 89-98. https://doi.org/10.37859/jae.v10i1.1934

Hartini, S. (2017). Hubungan orientasi pasar, strategi bersaing, kewirausahaan korporasi dan kinerja perusahaan. EKUITAS (Jurnal Ekonomi dan Keuangan), 17(1), 39. https://doi.org/10.24034/j25485024.y2013.v17.i1.2220

Kondoy, E., \& Rahman, R. (2020). Peluang usaha kecil kuliner rumahan masyarakat perum kharisma koka ditengah pandemi Covid 19. JISIP (Jurnal Ilmu Sosial dan Pendidikan), 4(3), 84-87. https://doi.org/10.36312/jisip.v4i3.1164

Kotler, P., \& Keller, K. (2012). Marketing Management (13th ed.). New Jersey: Prentice Hall International Inc.

Lindley, D. V. (1987). Regression and correlation analysis. New Palgrave: A Dictionary of Economics.

Marlinah, L. (2020). Peluang dan tantangan UMKM Dalam upaya memperkuat perekonomian nasional tahun 2020 di tengah pandemi Covid 19. Jurnal Ekonomi, 22(2), 118-124.

Nasution, D. A. D., Erlina, E., \& Muda, I. (2020). Dampak pandemi Covid-19 terhadap perekonomian Indonesia. Jurnal Benefita, 5(2), 212. https://doi.org/10.22216/jbe.v5i2.5313

Porter, M. (1998). Competitive advantage creative and sustaining superior performance. With a New Introduction. New York: The Free Pers.

Prianto, A., Kurniati, I., Wahyudi, M. T., \& Yulistia, E. (2020). Berbagai faktor penentu kesiapan untuk berubah dan pengaruhnya terhadap keberlangsungan kegiatan UMKM di wilayah terdampak wabah Covid-19. CAPITAL: Jurnal Ekonomi Da Manajemen, 4(1), 14-42.

Sriyanto. (2020). Pengaruh modal terhadap omzet penjualan: peran biaya pemasaran sebagai variabel moderating. Riset Manajemen dan Akuntansi, 11(1), 1-16.

Sugiri, D. (2020). Menyelamatkan usaha mikro, kecil dan menengah dari dampak pandemi Covid-19. Fokus Bisnis: Media Pengkajian Manajemen dan Akuntansi, 19(1), 76-86. https://doi.org/10.32639/fokusbisnis.v19i1.575

Sylvia, R., Mailiana, M., \& Fajar, R. (2019). Penerapan promosi penjualan untuk meningkatkan omset penjualan pada Ud Hamida Kue Banjarmasin. Dinamika Ekonomi-Jurnal Ekonomi dan Bisnis, 12(2), 314-324.

Tidd, J. and Bessant, J. (2009). Managing innovation: Integrating technological, market and organizational change. Wiley.

Willy, F., Goh, T. S., \& Julitawaty, W. (2020). Pengaruh personal selling dan promosi penjualan terhadap efektifitas penjualan ban sepeda motor pt . Mega anugrah mandiri. Jurnal Bisnis Kolega, $6(1), 43-56$. 